\title{
Social Software: Silver Bullet or an Enabler of Competitive Advantage?
}

\author{
Darshan Desai \\ Berkeley College, New York, USA \\ dndaBerkeleycollege.edu
}

\begin{abstract}
According to knowledge based view, firm-specific knowledge is considered to be a foundational source of competitive advantage. However, the recent trend towards social software radically changes the very essence, role, and value of firm-specific knowledge in driving competitive advantage. On one hand, firms are very enthusiastic about the investments in the social software initiatives; on the other hand, the broader strategic impact of these initiatives is not clear yet. This position paper highlights deep-seated problems in applying prominent strategic management theories in the context of social software. To address these problems, drawing on literature on value co-creation and service logic, it describes four ways social software can enable a firm's competitive advantage, and call for more research in this area.
\end{abstract}

Keywords: Knowledge, social software, competitive advantage.

\section{Introduction}

For years, strategy scholars have discussed how a firm gains competitive success. However, with the fast paced technological innovations, the concepts and frameworks of the past may no longer work today. For example, in the past, scholars (Kogut and Zander, 1995) have considered tacit and firm-specific knowledge to be fundamental source of competitive advantage. Firms have invested a lot in the knowledge management initiatives that included centrally managed, proprietary knowledge repositories. Today, when the locus of knowledge production is no longer confined within a firm's boundaries, the firm-specific knowledge is no longer sufficient for driving a competitive advantage. Social software supports group interactions, and provides open and inexpensive alternatives for the traditional knowledge management implementations. According to Von Krogh (2012), these social software implementations raise fundamental questions about the very essence and value of the firm-specific knowledge in driving competitive advantage.

With these technological advancements related to social software, today, there has been a profound shift in the roles of firms and customers in the process of knowledge and value co-creation. Empowered with internet and social media, customers have become more connected, informed, and active than ever before. Scholars (Vargo and Lusch, 2004) have well recognized the shift in the role of consumers. Despite the similar shift in the role of a firm, relatively little is known about it. A few scholars 
(Von Krogh, 2012; Haefliger, et al, 2011) have provided valuable insights by discussing the role of social software in changing knowledge management and strategic thinking. On one hand, software vendors claim that their social software works like silver bullets that lead to competitive advantages, and, the enthusiasm and investments for these initiatives are on the rise. On the other hand, the broader strategic impacts of these initiatives on competitive advantage are not clear yet.

Social software has potential to empower firms to be more engaged and active; however, it is important to draw on strategic management literature to explore whether and how it enables competitive advantage. This position paper highlights deep-seated problems in applying some of the prominent strategic management theories in the context of social software initiatives. To address these problems, drawing on marketing literature, it suggests four ways social software can enable a firm's competitive advantage and call for more research to extend the dynamic capability view.

\section{The Social Software and Strategy Management: Do They Match?}

In the strategy literature, resource-based view (Barney, 1991) and knowledge based view (Kogut and Zander, 1995) places the source of competitive advantage at the organizational level. These scholars argue that internal, difficult to transmit and firmspecific knowledge and resources are important sources of a firm's competitive advantage. However, over time, scholars recognized that a firm's internal stock of resources is not sufficient, and the flow of assets and knowledge resources are equally important for driving a competitive advantage. To acknowledge the importance of the flow of assets and external sources of competitive advantage, Teece et al., (1997) extended the resource based view, and presented the dynamic capability approach. According to the dynamic capability approach, when competitive landscapes are shifting, the dynamic capabilities by which managers "integrate, build, reconfigure, internal and external competencies to address rapidly changing environments" become sources of competitive advantage (Teece et al., 1997, p.516). Despite the recognition of the external competencies, due to its roots in resource based view, dynamic capability approach still remains internally focused, and considers enterprise-level dynamic capabilities to be the sources of a competitive advantage.

In these internally focused views, firm's internal value creation is considered to be disconnected from the market, and the customer-firm interface is considered to be a locus of extraction of economic value (Prahalad and Ramaswamy, 2004). Much of these strategy discussions focus on value extraction and capture, not on value cocreation. On the contrary, the social software is the crucial enabler of value cocreation. Social software boosts and facilitates the interaction between employees within and individuals outside the firm, such as members of user communities or customers (Haefliger, et al, 2011). It can enable customers to contribute to the firm's innovation and product development (Franke et al., 2010). It can also facilitate users of technology to organize themselves in communities, and innovate independently of manufacturers (von Hippel, 2007). In this context, to understand the impact of social software, strategy research should broaden the narrow perspective of authoritative 
decisions about technology adoption and myopic focus of value capture at the enterprise level (Haefliger, et al, 2011). The strategy research should also broaden their perspectives to shift due emphasis to the value co-creation and capability building at the system level.

\section{Value Co-creation and Competitive Advantage}

Effective leveraging of firm' internal resources and enterprise-level dynamic capabilities for superior delivery of customer value (value-in-exchange) is no longer sufficient for gaining competitive advantage. The prevailing view that the value for customers is embedded in the firms' offerings has been challenged by a view that value for customers emerges in customers' spears as value-in-use. Customers use the market offerings, and collaborate with other users, add other resources (goods, services, and information) and skills held by them, and create value-in-use (Gronroos, 2008). Superior value co-creation built up capabilities at the system level, and enhances the fitness of a firm's business ecosystem that leads to competitive advantage. As shown in Figure-1, most research in the dynamic capability literature focuses on enterprise level dynamic capability as source of competitive advantage. To understand the competitive advantage holistically, it is crucial to explore interactions between enterprise capabilities and fitness of business ecosystem.

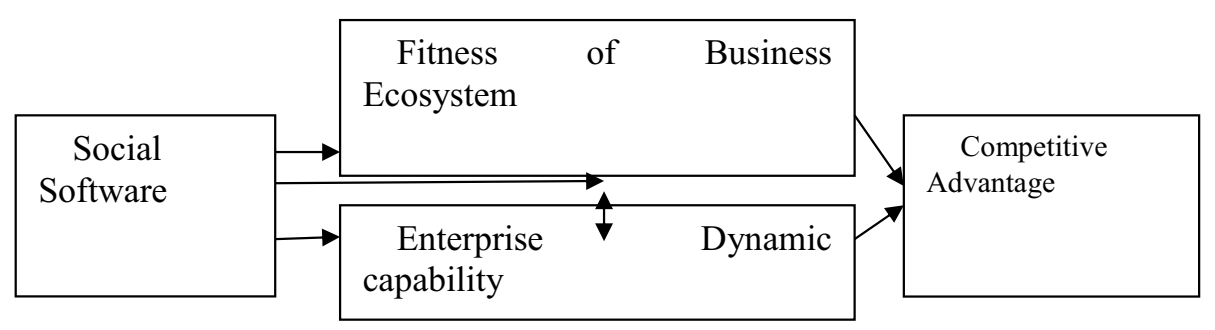

Fig. 1. Impact of Social Software on Competitive Advantage

\section{Social Software's Impact: Implications for Future Research}

Now to understand the impact of social software on competitive advantage, it is important to explore how it enables value co creation and value capture at the enterprise level and at the system level. Therefore, the impact of social software on competitive advantage can be analyzed in four different ways described in Table- 1 .

As shown in the analytical framework in Table-1, future research is needed to understand i) whether and how social software enable co-creation of superior valuein-use at the system level, ii) whether and how social software enable sustaining and protecting value-in-use at the system level, iii) whether and how social software enable value orchestration and co-creation at the enterprise level, and iv) whether and how social software enable competitive value capture and capability building at the enterprise level. This type of research that takes strategic approach on social software can generate valuable practical insights that are much needed by the practitioners and managers. 
Table 1. Social Software's impact on Competitive advantage

\begin{tabular}{|c|c|c|c|}
\hline & & \multicolumn{3}{|c|}{ Competitive Advantage } \\
\hline & & $\begin{array}{c}\text { Fitness of business eco } \\
\text { system }\end{array}$ & Enterprise-level dynamic capabilities \\
\hline $\begin{array}{c}\text { Social } \\
\text { Software } \\
\text { Enablem } \\
\text { ent }\end{array}$ & $\begin{array}{c}\text { Value co- } \\
\text { creation }\end{array}$ & $\begin{array}{c}\text { Value } \\
\text { Co-creation of superior } \\
\text { value-in-use at the system level }\end{array}$ & $\begin{array}{c}\text { Superior value orchestration and co- } \\
\text { creation at the enterprise -level }\end{array}$ \\
\cline { 2 - 5 } & $\begin{array}{c}\text { Sustaining and protecting } \\
\text { value-in-use at the system level }\end{array}$ & $\begin{array}{c}\text { Competitive value capture and capability } \\
\text { building at the enterprise level }\end{array}$ \\
\hline
\end{tabular}

\section{Conclusion}

This position paper highlights a key issue in applying prominent strategic management theories in the context of social software. According to this paper, applying the prominent theories to explore the impact of social software may give a myopic view. Prominent strategy management theories generally emphasize value extraction and capture at the enterprise-level more than value co-creation at the system level. On the contrary, the social software is the crucial enabler of value cocreation within a value network. Hence, to holistically understand the impact of social software on competitive advantage, it is important to explore how social software enables value co creation and value capture at the enterprise level and at the system level both. For this exploration, it is important to enrich the internally-focused prominent strategic management theories with the insights about value co-creation at the system level.

\section{References}

Barney, J.: Firm resources and sustained competitive advantage. Journal of Management 17(1), 99-120 (1991)

Franke, Nikolaus, Schreier, Martin, Kaiser, Ulrike: The 'I Designed It Myself' effect in mass customization. Management Science 56(1), 125-140 (2010)

Haefliger, S., Monteiro, E., Foray, D., von Krogh, G.: Introduction to Social Software and Strategy. Long Range Planning (2011)

Kogut, B., Zander, U.: Knowledge, market failure and the multinational enterprise: A reply. Journal of International Business Studies, 417-426 (1995)

Prahalad, C.K., Ramaswamy, V.: The Future of Competition: Co-Creating Unique Value with Customers. Harvard Business School Press, Boston (2004)

Teece, D.J., Pisano, G., Shuen, A.: Dynamic capabilities and strategic management. Strategic Management Journal 18(7), 509-533 (1997)

Vargo, S.L., Lusch, R.F.: Evolving to a new dominant logic for marketing. Journal of Marketing 68, 1-17 (2004)

von Hippel, Eric: Horizontal innovation networksdby and for users. Industrial and Corporate Change 16(2), 293-315 (2007)

Von Krogh, G.: How does social software change knowledge management? Toward a strategic research agenda. The Journal of Strategic Information Systems (2012) 